\title{
Keterlibatan Masyarakat dalam Program Rumah Tidak Layak Huni (RTLH) di Desa Pabedilankulon Kecamatan Pabedilan Kabupaten Cirebon
}

\author{
Nida Khoirunnisa \\ Mahasiswi Pascasarjana Ilmu Administrasi dan Kebijakan Publik, Fakultas Ilmu Administrasi, Universitas Indonesia, \\ nidakhoir1996@gmail.com

\section{Dr. Roy Valiant Salomo}

Dosen Fakultas Ilmu Administrasi, Universitas Indonesia, Royvsalomo2357@gmail.com

\begin{abstract}
Abstrak
Kemiskinan telah menjadi perhatian global yang perlu diperhatikan baik dari pemerintah maupun masyarakat. Masalah kemiskinan tidak bisa hanya diselesaikan oleh pemerintah semata, tetapi harus ada kontribusi dari semua pihak. Di negara berkembang dan maju, kemiskinan adalah masalah utama yang harus diperangi termasuk masalah kemiskinan di Indonesia. Hingga saat ini jumlah penduduk miskin semakin meningkat dan perlu diselesaikan serta dicari jalan keluarnya. Di Kabupaten Cirebon, Pemerintah Kabupaten Cirebon telah membuat beberapa kebijakan dalam penanggulangan kemiskinan, salah satunya adalah program Rumah Tidak Layak Huni (RTLH). Program Pemerintah Kabupaten Cirebon ini masih sangat dibutuhkan, mengingat masih banyak masyarakatnya yang berumah namun tak layak huni. Program ini berbentuk stimulan, harus ada keterlibatan dari masyarakat sekitar. Tujuan dalam penelitian ini adalah guna menganalisis keterlibatan masyarakat dalam program rumah tidak layak huni (RTLH) di Desa Pabedilankulon Kecamatan Pabedilan Kabupaten Cirebon. Metode penelitian yang digunakan adalah deskriptif kualitatif. Hasil penelitian menunjukkan bahwa keterlibatan masyarakat di Desa Pabedilankulon Kecamatan Pabedilan Kabupaten Cirebon belum berjalan optimal. Hal ini disebabkan oleh beberapa faktor yang mempengaruhi seperti kecemburuan sosial, peran pemimpin, ketidakmerataan sosialisasi program, kesadaran individu, dan tidak aktifnya organisasi masyarakat.
\end{abstract}

Kata Kunci: Keterlibatan Masyarakat, Rumah Tidak Layak Huni (RTLH) Program, Kemiskinan.

\begin{abstract}
Poverty has become a global concern that needs to be considered from both the government and the community. The problem of poverty cannot only be solved by the government, but there must be contributions from all parties. In developing and developed countries, poverty is a major problem that must be combated including the problem of poverty in Indonesia. Until now the number of poor people is increasing and needs to be completed and a solution is sought. In Cirebon Regency, the Cirebon District Government has made several policies in poverty reduction, one of which is program of house not livable (RTLH). The special program of the Cirebon Regency Government is still very much needed, considering that there are still many people who has home but not livable. This program is in the form of stimulants, there must be involvement from the surrounding community. The purpose of this study was to analyze the community in a house not livable program (RTLH) in Pabedilankulon Village, Pabedilan District, Cirebon Regency. The research method used is descriptive qualitative. The results showed that community involvement in Pabedilankulon Village, Pabedilan Subdistrict, Cirebon District had not run optimally. This is caused by several influencing factors such as social jealousy, the role of the leader, inequality in program socialization, individual awareness, and inactivity of community organizations.
\end{abstract}

Keywords: Community Involvement, House Not Livable (RTLH) Program, Poverty.

\section{PENDAHULUAN}

Kemiskinan (poverty) telah menjadi permasalahan global yang perlu diperhatikan baik dari pemerintah maupun masyarakat. Di negara berkembang maupun negara maju sekali pun, kemiskinan merupakan urgensi masalah utama untuk diperangi termasuk masalah kemiskinan di Indonesia. Seiring bertumbuhnya jumlah penduduk di Indonesia, sampai saat ini jumlah penduduk miskin semakin bertambah dan perlu dituntaskan serta dicari jalan keluarnya. Badan Pusat Statistik (BPS) mencatat persentase kemiskinan di Indonesia pada Maret
2018 yaitu $9,82 \%$ dari total jumlah penduduk Indonesia 265 juta jiwa.

Jumlah penduduk miskin atau pengeluaran per kapita tiap bulannya di bawah garis kemiskinan mencapai 25,95 juta jiwa. Berdasarkan daerah, fenomena kemiskinan di perdesaan menunjukkan peningkatan yang lebih luas dibandingkan perkotaan. Selama periode Maret 2018, jumlah penduduk miskin di daerah perdesaan sebanyak 15,81 juta jiwa, sedangkan di daerah perkotaan sebanyak 10,14 juta jiwa (Berita Resmi Badan Pusat Statistik Republik Indonesia, 2018). 
Pada tahun 2017 jumlah penduduk miskin di Kabupaten Cirebon sebanyak 279,55 ribu jiwa dari 2,6 juta jiwa penduduk, berada pada peringkat ke-3 setelah Kabupaten Bogor dan Kabupaten Garut. Jika dilihat tingkat kemiskinan di Kabupaten Cirebon pada tahun 2012-2017 (Maret) mengalami fluktuatif. Angka kemiskinan tertinggi di Kabupaten Cirebon yaitu pada tahun 2015 sebanyak 313,21 ribu jiwa dan mengalami penurunan pada tahun 2017 yakni 279,55 ribu jiwa (Badan Pusat Statistik Jawa Barat Tahun 2017).

Dalam mengantisipasi peningkatan angka kemiskinan di Kabupaten Cirebon, Pemerintah Daerah Kabupaten Cirebon membuat beberapa kebijakan dalam penanggulangan kemiskinan, salah satunya adalah program rumah tidak layak huni (RTLH). Program rutilahu dari Pemerintah Kabupaten Cirebon ini masih sangat diperlukan sekali, mengingat masih banyak masyarakat yang berumah namun tak layak huni. Landasan Pemerintah Daerah Kabupaten Cirebon dalam melaksanakan rutilahu yaitu berpedoman pada Permensos RI 20/2017 tentang Rehabilitasi Sosial Rumah Tidak Layak Huni dan Sarana Prasarana Lingkungan (RSRutilahu dan Sarpras Lingkungan).

Permensos 20/2017 dalam pasal 1 ayat 1 mengenai pengertian dan gambaran dari rumah tidak layak huni itu sendiri adalah "Rumah Tidak Layak Huni yang selanjutnya disebut Rutilahu adalah tempat tinggal yang tidak memenuhi syarat kesehatan, keamanan, dan sosial."

Kriteria RTLH yakni ketika rumah bermasalah dalam ALADIN (Atap, Lantai, Dinding). Jika ketiga hal tersebut masuk kriteria, maka dikatakan layak untuk menerima bantuan dari Dinas Sosial. Bantuan ini sifatnya stimulan, harus ada swadaya baik dari penerima bantuan, keluarga terdekat, ataupun tetangga sekitarnya. Jika tidak, rumah yang dibangun akan sama kondisinya dengan sebelumnya masih tetap menjadi rumah tidak layak huni karena biaya yang Pemerintah Daerah berikan tidak seberapa.

Penanggung jawab utama implementasi program RTLH dalam penanggulangan kemiskinan Di Kabupaten Cirebon adalah Dinas Sosial dibantu oleh stakeholder terkait yakni Dinas Perumahan Kawasan Permukiman dan Pertanahan dalam menggambar rumah beserta RAB (Rancangan Anggaran Biaya).

Jika melihat hasil penelitian terdahulu terdapat dua aspek RLTH yang menjadi prioritas penanganan ketidaklayakan hunian di kawasan Metropolitan Bandung Raya yaitu ketersediaan sumber air minum bersih dan sistem sanitasi (Vitriana, 2018). Di sisi lain, jika dilihat dari hasil monitoring dan evaluasi yang pernah dilakukan oleh Pemerintah Provinsi Kalimantan Timur di Kota Samarinda ditemukan beberapa permasalahan dalam Rumah Layak Huni, antara lain: masalah salahnya sasaran penerima bantuan RLH, adanya orang/ oknum tertentu yang memanfaatkan momen ini untuk kepentingan pribadi, adanya Rumah Layak Huni yang dijual, masalah kualitas dan kuantitas Rumah Layak Huni yang tidak sesuai spesifikasi, dan lain sebagainya (Abbas, 2015).

Begitu pun permasalahan implementasi program RS-RTLH di Kota Serang yaitu proses pencairan dana tidak memiliki kepastian waktu yang jelas. Masih terkendalanya pelaksanaan program RS-RTLH yang kurang sesuai dengan juknis pelaksanaan. Belum semua pihak terlibat seperti Kecamatan dan Kelurahan dalam pelaksanaan. Sosialisasi belum berjalan optimal (Nugraha, 2014).

Sedangkan, permasalahan global yang timbul dari adanya implementasi program RTLH di Kabupaten Cirebon adalah semua orang ingin miskin, ingin rumahnya di rehabilitasi total. Padahal kebijakan program ini sebetulnya hanya untuk penerima bantuan yang rumahnya jika diperbaiki dengan dana bantuan dari Pemerintah Kabupaten maka setidaknya rumah tersebut bisa berdiri kokoh jika angin kencang melanda, bukan rumah yang harus di bangun dari nol. Namun nyatanya, masih banyak masyarakat dengan keadaan rumah sama sekali bobrok dan diharuskan untuk dibangun dari nol dan dengan bersikeras meminta bantuan dari pemerintah daerah. Ada pula rumah yang hanya bagian dapurnya saja bermasalah karena pendukung atasan maka masyarakat tersebut meminta bantuan dengan perilaku yang tak patut dilakukan kepada Dinas Sosial Kabupaten Cirebon.

Kegiatan Rehabilitasi Sosial Keluarga Berumah Tidak Layak Huni (RS-KBTLH) di Kabupaten Cirebon dilaksanakan setiap tahun. Bantuan modal perunit rumah diambil dari dana Anggaran Pendapatan Belanja Daerah (APBD) Kabupaten Cirebon sebesar Rp. 13.500.000 dengan total anggaran tahun 2018 sebanyak Rp. 6.582.597.300. Jumlah total realisasi program rutilahu di Kabupaten Cirebon yang telah ditangani oleh Dinas Sosial berjumlah 3.230 unit yang tersebar di 40 Kecamatan.

Berdasarkan Permensos No. 20/ 2017 pasal 19 dalam bab IV mengenai bantuan sosial dan pemanfaatan dikatakan bahwa "Kelompok penerima bantuan sosial melaksanakan pembangunan/ perbaikan RTLH dan/ atau Sarana Lingkungan dilakukan secara bergotong-royong dan tidak bisa dipihakketigakan.

Namun kenyataannya, di jaman sekarang ini tukang dari sanak saudara pun meminta upah, karena pada umumnya sama-sama kekurangan dan mempunyai keluarga yang harus dibiayai. Oleh karenanya implementasi program RTLH ini merupakan tugas bersama bukan hanya Pemerintah Daerah saja yang menangani, namun perlu adanya keterlibatan berbagai 
pihak dalam mensukseskan jalannya program RTLH di Kabupaten Cirebon, termasuk keterlibatan masyarakat dalam mensukseskan jalannya program RTLH di Kabupaten Cirebon. Fakta di lapangan menunjukkan bahwa keterlibatan masyarakat di Desa Pabedilankulon pun belum berjalan optimal, seperti yang penulis dapatkan dari hasil wawancara dengan Kepala Urusan Perencanaan dan lima (5) penerima bantuan di Desa Pabedilankulon Kecamatan Pabedilan Kabupaten Cirebon.

Alasan penulis mengambil objek penelitian di Desa Pabedilankulon Kecamatan Pabedilan Kabupaten Cirebon adalah karena Desa Pabedilankulon merupakan desa yang memiliki jumlah target RTLH tertinggi di wilayah Cirebon Timur, yaitu 250 rumah pada 2017. Mata pencaharian masyarakat Desa Pabedilankulon adalah petani dan buruh. Namun, dengan situasi yang masih banyak target RTLH dan kental dengan budaya pedesaan ternyata tidak sebanding dengan semangat gotong royong untuk melakukan swadaya dan keterlibatan masyarakat dalam program RTLH.

Menurut Cohen dan Uphoff (1977), partisipasi termasuk keterlibatan orang dalam proses pengambilan keputusan, dalam melaksanakan program, pembagian manfaat program pembangunan dan keterlibatan mereka dalam upaya untuk mengevaluasi program tersebut. Sedangkan Pemberdayaan adalah kemampuan individu untuk mendapatkan kontrol sosial, politik, ekonomi, dan psikologis melalui (1) akses ke informasi, pengetahuan, dan keterampilan; (2) pengambilan keputusan; dan (3) efikasi diri individu, partisipasi masyarakat, dan kontrol yang dirasakan (Rappaport 1987; Zimmerman dan Rappaport 1988).

Mubyarto (2004) mendefinisikan kemiskinan bahwa: "Kemiskinan di gambarkan sebagai kurangnya pendapatan untuk memenuhi kebutuhan hidup yang pokok atau kebutuhan hidup minimum yaitu sandang, pangan, perumahan, pendidikan dan kesehatan.

Melihat berbagai permasalahan keterlibatan masyarakat dalam program RTLH di Desa Pabedilankulon Kecamatan Pabedilan Kabupaten Cirebon, maka permasalahan yang perlu diangkat dalam penelitian ini adalah :

1. Bagaimana keterlibatan masyarakat dalam program RTLH di Desa Pabedilankulon Kecamatan Pabedilan Kabupaten Cirebon?

2. Faktor-faktor apa saja yang mempengaruhi keterlibatan masyarakat dalam program RTLH di Desa Pabedilankulon Kecamatan Pabedilan Kabupaten Cirebon?

\section{METODE}

Penelitian ini menggunakan metode deskriptif kualitatif dengan teknik pengumpulan data metode wawancara, dan studi dokumen. Teknik analisis data dalam penelitian ini dilakukan dengan triangulasi sumber. Metode wawancara dan studi dokumen dilakukan di Desa Pabedilankulon, Kecamatan Pabedilan, Kabupaten Cirebon. Informan dalam penelitian ini adalah Kepala Urusan Perencanaan di Balai Desa Pabedilankulon dan lima (5) masyarakat penerima bantuan untuk mendapatkan gambaran yang mendalam mengenai keterlibatan masyarakat dan faktor-faktor yang mempengaruhinya dalam program RTLH di Desa Pabedilankulon, Kecamatan Pabedilan, Kabupaten Cirebon. Penelitian ini dilakukan \pm dua minggu terhitung tanggal 4-18 Maret 2019.

\section{HASIL DAN PEMBAHASAN}

\section{A. Gambaran Umum Keterlibatan Masyarakat dalam Program RTLH di Desa Pabedilankulon Kecamatan Pabedilan Kabupaten Cirebon}

Desa Pabedilankulon Kecamatan Pabedilan merupakan bagian tak terpisahkan dari Wilayah Kabupaten Cirebon yang merupakan masyarakat agraris, dengan potensi alam yang dimiliki terbesar adalah sektor pertanian yang terhampar luas dengan kesuburan tanah yang cukup baik. Namun jika melihat kondisi rumah pada profil Desa Pabedilankulon tahun 2017, rumah layak huni (RLH) berjumlah 718 rumah dan rumah tidak layak huni (RTLH) berjumlah 250 rumah. Jumlah Keluarga Miskin (Gakin) sebanyak $530 \mathrm{KK}$, dengan persentase 23,77\% dari jumlah yang ada di Desa Pabedilankulon.

Dalam mengurangi angka RTLH di Desa Pabedilankulon, maka Pemerintah Daerah memberikan bantuan perbaikan rumah bagi masyarakat penerima manfaat di Desa tersebut. Program RTLH ini adalah pengharapan terciptanya kondisi masyarakat yang mampu mengubah prilaku hidup sehat, sadar akan lingkungan yang bersih dan sehat, dan sebagai salah satu pemenuhan kebutuhan dasar hidup manusia untuk mencapai kesejahteraan. Dalam program RTLH ini diharapkan terwujudnya perumahan yang layak huni, sehat, aman dan teratur dalam lingkungan sekitar serta mampu menumbuhkan semangat bergotong royong dalam pemugaran/ rehabilitasi RTLH yang ada di Desa Pabedilankulon Kecamatan Pabedilan Kabupaten Cirebon.

Permasalahan atau kendala yang selama ini dihadapi/ ditemukan RTLH semakin meningkat ditengah kehidupan yang padat penduduknya. Seiring dengan permasalahan perekonomian yang semakin memberatkan masyarakat khususnya permasalahan RTLH ditengah pemukiman padat penduduk di Desa Pabedilankulon. Ditambah tingkat penghasilan yang tidak mencukupi untuk melakukan pemugaran/ rehabilitasi secara berdikari memberikan dampak nyata terhadap perilaku hidup sehat 
bahkan rendahnya tingkat kesehatan juga akan memberikan dampak pada lingkungan di sekitarnya. Contoh seperti rumah yang kurang sinar matahari, lembab, hampir rubuh, kumuh adalah tempat berkumpulnya kuman, binatang pembawa penyakit dan lain sebagainya. Hal ini akan berdampak pula pada penyebaran penyakit menular di lingkungan. Untuk itu perlu adanya keterlibatan masyarakat dalam hal gotong royong membantu warga yang menerima bantuan program RTLH dari Pemerintah Daerah.

Namun nyatanya, semangat partisipasi dari masyarakat sekitar pun kian memudar. Rasa gotong royong antar sesama sudah jarang ditemui di pedesaan tepatnya di Desa Pabedilankulon Kecamatan Pabedilan Kabupaten Cirebon. Padahal di Desa Pabedilankulon masih banyak masyarakatnya yang berumah namun tak layak huni. Rata-rata dari mereka pun bermata pencaharian sebagai buruh dan petani. Nampaknya, rasa simpati antar sesama tidak seperti pada jaman dahulu kala yang banyak ditemukan semangat gotong royong dalam membantu.

\section{B. Faktor-Faktor yang Mempengaruhi Keterlibatan Masyarakat dalam Program Rutilahu di Desa Pabedilankulon Kecamatan Pabedilan Kabupaten Cirebon}

Faktor-faktor yang mempengaruhi keterlibatan masyarakat dalam program RTLH di Desa Pabedilankulon Kecamatan Pabedilan Kabupaten Cirebon salah satunya adalah rasa kecemburuan sosial antar sesama. Seperti yang diungkapkan oleh Kepala Urusan (Kaur) Perencanaan Desa Pabedilankulon Kecamatan Pabedilan Kabupaten Cirebon ketika diwawancarai pada 13 Maret 2019 perihal kendala di lapangan adalah sebagai berikut:

"Kendala di lapangan diantaranya adalah upah tukang kalau bukan saudara sendiri pengen harganya sama seperti harga pada umumnya, kita sebagai orang Desa menasehati untuk dikorting harganya."

Dari hasil kutipan wawancara di atas mengenai kendala di lapangan yaitu tukang yang notabene diambil dari tetangga atau sanak saudara sebagai pemberdayaan masyarakat sekitar pun tidak mau upahnya dikurangi untuk membantu sesama. Padahal seharusnya tukang tersebut mengerti bahwa ini merupakan program Pemerintah Daerah terkait perbaikan rumah bagi warga miskin yang mana KPM (Kelompok Penerima Manfaat) merupakan tetangganya sendiri. Namun ketika dimintai tolong untuk membangun rumah dalam program RTLH Pemerintah Daerah tidak ada rasa kepedulian sosial dari masyarakat sekitarnya.
Selain kendala mengenai harga tukang yang tak mau dikorting, ada juga kendala lain di lapangan yang dihadapi oleh Kaur Perencanaan yang berhubungan langsung dengan pelaksanaan. Transkrip wawancara dengan Kaur Perencanaan pada 13 Maret 2019 mengenai kendala lainnya di lapangan dapat dilihat pada kutipan di bawah ini "Kecemburuan sosial antar masyarakat masih tinggi. Untung sekarang bisa dicover oleh dana Desa jadi Pemerintahan Desa sedikit tenang."

Tingginya faktor kecemburuan sosial antar masyarakat menjadi kendala Pemerintah Desa dalam hal menanggulanginya. Namun, dengan adanya dana Desa yang bisa digunakan untuk perbaikan rumah bagi warga miskin setidaknya sedikit mengurangi rasa kecemburuan sosial antar masyarakat di Desa Pabedilankulon. Karena sebelum adanya pemberdayaan dari dana Desa untuk program RTLH Pemerintah Daerah, kecemburuan sosial antar warga di Desa Pabedilankulon Kecamatan Pabedilan Kabupaten Cirebon masih tinggi.

Ketika ditanya perihal gotong royong sendiri Kaur Perencanaan menjelaskan bahwa :

"Gotong royongnya lumayan ada swadaya dari masyarakat sekitar, contohnya kalau rumah lagi dihancurin masyarakat/ saudara bantu bawain pasir dari luar ke dalam, bantu ngaduk semen, dll. Paling susah memang poin gotong royong. Orang sekarang sudah susah untuk menumbuhkan rasa gotong royong. Sedangkan pembangunan RTLH kita targetkan 10-14 hari sudah nutup/ selesai."

Dari hasil kutipan wawancara di atas bahwa poin gotong royong adalah poin tersulit di Desa Pabedilankulon dalam program RTLH. Untuk menumbuhkan kembali rasa kepedulian antar sesama memang dibutuhkan keluwesan dan kesabaran dari Perangkat Desa untuk membujuk masyarakat sekitar agar ikut serta membantu tetangganya yang mendapatkan bantuan perbaikan rumah dari Pemerintah Daerah. Walaupun ada swadaya itu sifatnya hanya membantu dalam hal tenaga, itu pun kebanyakan dari sanak saudara sendiri, masyarakat sekitarnya masih acuh tak acuh untuk membantu. Ada sebagian masyarakat sekitar juga yang ikut serta membantu dalam hal tenanga, itu pun yang bebannya ringan. Namun setidaknya masih ada masyarakat yang mau menolong sesamanya.

Ketika ditanya mengenai aspek gotong royong kepada kelima (5) penerima bantuan di Desa Pabedilankulon Kecamatan Pabedilan Kabupaten Cirebon rata-rata jawabannya adalah ada beberapa tetangga yang membantu dalam hal tenaga seperti ngangkat batu, semen, ngaduk ini itu seperti yang diungkapkan oleh Kepala Urusan Perencanaan di Desa Pabedilankulon di atas. Ini disebabkan karena sosialisasi 
program yang belum merata hingga ke kalangan masyarakat. Banyak masyarakat yang tidak mengetahui teknis pelaksanaan program RTLH di lapangan.

Faktor lainnya yang mempengaruhi keterlibatan masyarakat dalam program RTLH menurut Kaur Perencanaan diantaranya ialah :

"Peran pimpinan juga sangat penting, dalam hal ini Kepala Dusun. Kepala Dusun yang mengerti maka mengadakan patungan dan mendatangi rumah perumah untuk ikut serta membantu warga yang menerima bantuan RTLH. Namun nyatanya tidak banyak Kepala Dusun yang melakukan hal ini di Desa Pabedilankulon."

Selain peran pemimpin dalam hal ini Kepala Dusun yang dapat mempengaruhi keterlibatan masyarakat, Kaur Perencanaan pada 13 Maret 2019 juga menjelaskan faktor lainnya ialah :

"Tidak aktifnya organisasi masyarakat seperti halnya Karang Taruna yang menjadikan keterlibatan masyarakat semakin berkurang. Siapa lagi jika tidak organisasi masyarakat itu sendiri yang meningkatkan kepeduliannya terhadap masyarakat sekitar."

Ini yang ingin digalakkan oleh Desa Pabedilankulon agar Karang Taruna diaktifkan kembali atau dilibatkan dalam kepanitian program RTLH. Sehingga, semangat membantu dari masyarakat kembali membara. Dan ke-lima faktor ini semua yang dapat mempercepat maupun memperlambat jalannya suatu program sesuai visi, misi, dan tujuan bersama yang telah disepakati.

Kebutuhan akan rumah tinggal yang layak huni adalah suatu strategi dalam upaya peningkatan derajat kesehatan dan penciptaan lingkungan yang sehat dan aman. Pengalaman empirik di beberapa tempat menunjukkan bahwa strategi pemugaran/ rehabilitasi rumah tidak layak huni ditengah pemukiman padat penduduk pada anggota masyarakat yang tidak memiliki kemampuan ekonomi untuk mengatasi sendiri pemugaran rumah tinggal mereka akan membawa perubahan dalam prilaku hidup sehat. Ditambah kehidupan kesehatan keluarga menjadi lebih baik dan juga berdampak pada kehidupan kesehatan lingkungan secara umum.

Dilatar belakangi oleh pengalaman yang selama ini membuktikan bahwa bila kondisi rumah tidak layak huni kemudian direhabilitasi menjadi layak huni, perilaku hidup sehat serta tingkat kesehatan keluarga akan meningkat ditambah masalah kesehatan sosial akan berkurang. Dengan adanya program Rumah Tidak Layak Huni (RTLH) dapat mengatasi sedikitnya permasalahan pemukiman secara umum di Desa Pabedilankulon Kecamatan Pabedilan Kabupaten Cirebon.
Tujuan program rumah tidak layak huni (RTLH) ini adalah pengharapan terciptanya kondisi masyarakat yang mampu mengubah prilaku hidup sehat, sadar akan lingkungan yang bersih dan sehat, dan sebagai salah satu pemenuhan kebutuhan dasar hidup manusia untuk mencapai kesejahteraan. Dengan program rumah tidak layak huni ini diharapkan terwujudnya perumahan yang layak huni, sehat, aman dan teratur dalam lingkungan sekitar serta mampu menumbuhkan semangat bergotong royong dalam pemugaran/ rehabilitasi rumah tidak layak huni yang ada di Desa Pabedilankulon Kecamatan Pabedilan Kabupaten Cirebon.

Permasalahan atau kendala yang selama ini dihadapi/ ditemukan bahwa rumah yang tidak layak huni semakin meningkat ditengah kehidupan yang padat penduduknya, seiring dengan permasalahan perekonomian yang semakin memberatkan masyarakat khususnya permasalahan rumah tidak layak huni ditengah pemukiman padat penduduk di Desa Pabedilankulon. Ditambah tingkat penghasilan yang tidak mencukupi untuk melakukan pemugaran/ rehabilitasi secara berdikari memberikan dampak nyata terhadap prilaku hidup sehat mereka bahkan rendahnya tingkat kesehatan, juga akan memberikan dampak pada lingkungan disekitarnya. Contoh seperti rumah yang kurang sinar matahari, lembab, hampir rubuh, kumuh adalah tempat berkumpulnya kuman, binatang pembawa penyakit dan lain sebagainya. Hal ini akan berdampak pula pada penyebaran penyakit menular dilingkungan.

Pada tahun 2016 Desa Pabedilankulon mengusulkan proposal rumah dalam program RTLH sebanyak 15 rumah dan di tahun 2017 terealisasi 15 unit rumah [23]. Hal tersebut belum mampu mencover jumlah RTLH yang harus diberantas karena minimnya anggaran Pemda dan pembagian masalah sosial lainnya yang mengharuskan dibagi rata. Namun, baik dari Pemdes maupun masyarakat sudah merasa bersyukur dengan adanya bantuan tersebut walaupun nominal bantuan tidak sesuai dengan pengharapan Desa dalam proposal pengajuan rutilahu. Setidaknya bantuan tersebut dapat membantu memberikan tempat tinggal yang layak bagi masyarakat di Desa Pabedilankulon yang masih banyak RTLH nya. Agar penyelesaian RTLH di Desa Pabedilankulon dapat teratasi dengan baik dan cepat, semangat gotong royong dalam hal ini keterlibatan masyarakat perlu digalakkan kembali karena di jaman sekarang ini hal tersebut minim sekali ditemukan di Desa Pabedilankulon Kabupaten Cirebon. Begitu pun dengan faktor-faktor yang mempengaruhi keterlibatan masyarakat perlu diminimalisir sedemikian rupa agar program RTLH dapat berjalan dengan baik.

Dalam aturan Permensos Nomor 20/ 2017 sudah dijelaskan bahwa program ini sifatnya stimulan. Harus 
dilakukan gotong royong dari masyarakat sekitar dan penerima bantuan harus menambahkan anggaran sendiri agar rumah dibangun dengan baik dan sesuai dengan permintaan. Dalam program RTLH ini tanah harus merupakan tanah milik pribadi bukan tanah yang menumpang dari tetangga sebelah atau tanah sengketa. Sertifikat tanah harus atas nama penerima program RTLH.

Pembelian bahan material dibelikan oleh tim pelaksana rutilahu dan masyarakat penerima bantuan. bahan-bahan material dibeli sesuai dengan permintaan penerima bantuan yang sudah tercantum dalam Rancangan Anggaran Biaya (RAB). Ketika ada pemberdayaan dari masyarakat sekitar ataupun penambahan anggaran pribadi dari penerima bantuan maka program RTLH ini dapat berjalan dengan baik. Jika tidak ada sama sekali swadaya dari penerima bantuan maka rumah akan dibangun sesuai dengan jumlah nominal bantuan. Namun, di Desa Pabedilankulon masyarakat penerima bantuan rata-rata ada penambahan anggaran pribadi. Sedangkan untuk keterlibatan masyarakat sekitar belum berjalan maksimal.

Menurut Cohen dan Uphoff (1977), partisipasi termasuk keterlibatan orang dalam proses pengambilan keputusan, dalam melaksanakan program, pembagian manfaat program pembangunan dan keterlibatan dalam upaya untuk mengevaluasi program tersebut. Sedangkan Pemberdayaan adalah kemampuan individu untuk mendapatkan kontrol sosial, politik, ekonomi, dan psikologis melalui (1) akses ke informasi, pengetahuan, dan keterampilan; (2) pengambilan keputusan; dan (3) efikasi diri individu, partisipasi masyarakat, dan kontrol yang dirasakan (Rappaport 1987; Zimmerman dan Rappaport 1988).

Dari teori partisipasi dan pemberdayaan di atas, kondisi di lapangannya adalah bahwa keterlibatan masyarakat di Desa Pabedilankulon Kecamatan Pabedilan Kabupaten Cirebon belum terlibat langsung baik dalam hal pengambilan keputusan, pelaksanaan program, dan keterlibatan dalam evaluasi program. Dengan demikian diperlukan partisipasi dan pemberdayaan dari masyarakatnya agar masyarakat mendapatkan kontrol sosial, politik, ekonomi, dan psikologis melalui akses ke informasi, pengetahuan, dan keterampilan; pengambilan keputusan; dan efikasi diri individu, partisipasi masyarakat, dan kontrol yang dirasakan dari adanya program RTLH Pemda ini.

\section{PENUTUP}

\section{Simpulan}

Melihat pembahasan yang telah dijabarkan di atas bahwa keterlibatan masyarakat dalam program RTLH di
Desa Pabedilankulon Kecamatan Pabedilan Kabupaten Cirebon belum berjalan optimal. Hal ini disebabkan oleh beberapa faktor yang mempengaruhi, seperti: kecemburuan sosial, peran pemimpin, sosialisasi program yang belum merata, kesadaran individu, dan tidak aktifnya organisasi masyarakat. Perlu adanya penanaman nilai-nilai kepedulian sosial dan semangat gotong royong kembali untuk membantu masyarakat sekitarnya.

Dalam program RTLH ini sifatnya stimulan, harus ada swadaya dari masyarakat sekitar ataupun dari penerima bantuan itu sendiri. Dana yang Pemerintah Daerah berikan tidak seberapa. Oleh karena itu jika penerima bantuan tidak ada swadaya sama sekali maka rumah akan dibangun dengan seadanya dan secukupnya dari dana bantuan tersebut. Terlebih jika masyarakat sekitar pun tidak serta merta ikut membantu masyarakat yang menerima bantuan, maka dana tersebut digunakan semaksimal mungkin agar bangunan tetap terbangun dengan kokoh. Aturan dalam program RTLH pun menganjurkan untuk dilakukan gotong royong. Sehingga keterlibatan masyarakat dalam semangat gotong royong perlu ditingkatkan kembali di Desa Pabedilankulon Kecamatan Pabedilan Kabupaten Cirebon.

\section{Saran}

Diperlukan adanya penumbuhan kembali tingkat partisipasi dan pemberdayaan masyarakat di Desa Pabedilankulon Kecamatan Pabedilan Kabupaten Cirebon dengan cara pemerataan sosialisasi program, pengaktifan kembali organisasi masyarakat, serta peranan dari Perangkat Desa Pabedilankulon untuk tidak bosan memberikan nasehat dan wejangannya kepada masyarakat di Desa Pabedilankulon Kecamatan Pabedilan Kabupaten Cirebon dalam hal keikutsetaan masyarakat dalam program RTLH yang Pemerintah Daerah berikan.

\section{DAFTAR PUSTAKA}

Abbas, ibnu. 2015. Evaluasi Kebijakan Pembangunan Rumah Layak Huni Bagi Masyarakat Miskin di Kota Samarinda Provinsi Kalimantan Timur. Jurnal Paradigma. Vol. 4, no. 2.

Berita Resmi Badan Pusat Statistik Republik Indonesia Tahun 2018.

Badan Pusat Statistik Jawa Barat Tahun 2017.

Cohen, J. and N. Uphoff. 1977. Rural Development Participation: Concepts and Measures for Project Design. Implementation and Evaluation, Ithaka: Cornel University.

Mubyarto. 2004. Kemiskinan, Pengangguran, dan Ekonom Indonesia. Jurnal Dinamika Masyarakat. Vol. III, no. 2. 
Nugraha, Adi Fajar. 2014. Implementasi Program Rehabilitasi Sosial Rumah Tidak Layak Huni (RSRTLH). Skripsi diterbitkan. Serang: Universitas Sultan Ageng Tirtayasa.

Peraturan Menteri Sosial Republik Indonesia Nomor 20 Tahun 2017 tentang Rehabilitasi Sosial Rumah Tidak Layak Huni dan Sarana Prasarana Lingkungan.

Profil Desa Pabedilankulon Kecamatan Pabedilan Kabupaten Cirebon Tahun 2017.

Proposal Permohonan Bantuan Biaya Rumah Tidak Layak Huni Desa Pabedilankulon Kecamatan Pabedilan Kabupaten Cirebon Tahun 2017.

Rappaport, J. (1987). "Terms of Empowerment? Examplars of Prevention: Toward a Theory for Community Phsychology." Amercian journal of community phsychology 15(2): 121-148.

Zimmerman, M. and J. Rappaport (1988). "Citizan participation, percived control and phsychological empowerment." Amercian journal of community phsychology 16(5): 725-750. 